Original Article

\title{
Effects of 12-week circuit exercise program on obesity index, appetite regulating hormones, and insulin resistance in middle-aged obese females
}

Seol-Jung Kang, PhD ${ }^{1)}$, Jong-Hyu Kim, PhD ${ }^{2)}$, Zhao Gang, PhD ${ }^{3)}$, Young-Sook Yook, PhD ${ }^{4}$, Jea-Ryang Yoon, $\mathrm{PhD}^{5}$, Gi-Chul Ha, $\mathrm{MS}^{5)}$, Kwang-Jun Ko, $\mathrm{PhD}^{6}$ * $^{*}$

1) Department of Physical Education, Changwon National University, Republic of Korea

2) Health Care Center, Department of Preventive Medicine, Chonbuk National University, Republic of Korea

3) Department of Physical Education, Shenzhen University, China

4) Department of Exercise Rehabilitation Welfare, Sungshin Women's University, Republic of Korea

5) Department of Physical Education, Korea National Sport University, Republic of Korea

6) Department of Sports Medicine, National Health Fitness Center: 424 Olympicro, Songpagu, Seoul 05540, Republic of Korea

\begin{abstract}
Purpose] The purpose of this study is to investigate the effects of circuit exercise on obesity index, appetite regulating hormones and insulin resistance in middle-aged obese women. [Subjects and Methods] The subjects of this study were 26 obese middle-aged women who were selected among participants in exercise class at K Region Health Promotion Center in South Korea and were randomly assigned to the exercise group ( $\mathrm{n}=13$; age $50.15 \pm 3.82, \%$ body fat $38.79 \pm 3.28$ ) and the control group ( $\mathrm{n}=13$; age $49.84 \pm 2.96, \%$ body fat $37.46 \pm 2.51)$. Circuit exercise consisted of aerobic exercise and resistance exercise for 5 weeks and 50 minutes for 12 weeks. Before and after exercise we measured obesity index, leptin, ghrelin, fasting blood glucose, insulin, and insulin resistance in all subjects. A repeated-measured two-way of variance was performed for comparison of the treatment effects between the exercise and control groups. [Results] Body weight, BMI, and body fat percentage of obese index decreased significantly. Leptin of dietary regulation hormone was significantly decreased and ghrelin was significantly increased. Insulin and insulin resistance was significantly decreased. [Conclusion] Circuit exercise can be viewed as an effective exercise program to induce changes in appetite regulating hormones and to improve insulin resistance by mechanisms of energy homeostasis by weight loss.

Key words: Circuit exercise, Leptin, Ghrelin
\end{abstract}

(This article was submitted Jul. 21, 2017, and was accepted Oct. 30, 2017)

\section{INTRODUCTION}

Obesity is clinically important since it can increase the risk of cancer, metabolic diseases, and musculoskeletal diseases, which can be fatal ${ }^{1,2)}$. Obesity is caused by imbalance in the energy homeostasis system. In other words, obesity is seen when the energy absorption from food, heat production, and energy consumption via bodily activities are not synchronized ${ }^{3)}$. Food intake directly correlates with energy absorption, representing a complementary association between satiety and hunger, regulated by ghrelin and leptin ${ }^{4}$.

Leptin is a cytokine secreted by adipose tissues that suppresses hunger by acting on the arcuate nucleus in the hypothalamus ${ }^{5}$. Despite the action of leptin, a paradoxical phenomenon causes a high level of leptin to be detected in the serum

*Corresponding author. Kwang-Jun Ko (E-mail: tigerkor80@naver.com)

(C2018 The Society of Physical Therapy Science. Published by IPEC Inc.

This is an open-access article distributed under the terms of the Creative Commons Attribution Non-Commercial No Derivatives (by-nc-nd) License. (CC-BY-NC-ND 4.0: https://creativecommons.org/licenses/by-nc-nd/4.0/) 
Table 1. Characteristics of subjects

\begin{tabular}{clllcl}
\hline \multicolumn{1}{c}{ Group } & Age (yrs) & Height $(\mathrm{cm})$ & Weight $(\mathrm{kg})$ & BMI $\left(\mathrm{kg} / \mathrm{m}^{2}\right)$ & Body fat $(\%)$ \\
\hline Exercise $(\mathrm{n}=13)$ & $50.1 \pm 3.8$ & $160.9 \pm 4.7$ & $82.7 \pm 10.4$ & $31.8 \pm 3.2$ & $38.79 \pm 3.28$ \\
Control $(\mathrm{n}=13)$ & $49.8 \pm 2.9$ & $158.9 \pm 4.8$ & $77.2 \pm 9.6$ & $30.4 \pm 2.3$ & $37.46 \pm 2.51$ \\
\hline
\end{tabular}

Valves are Mean \pm SD.

BMI: Body Mass Index.

of obese individuals due to development of leptin resistance. High leptinemia inhibits oxidation of fatty acids and causes insulin resistance ${ }^{6}$. On the other hand, ghrelin is secreted by the gastrointestinal system with hunger and increases appetite while decreasing leptin effects ${ }^{7)}$. In obese individuals, ghrelin levels are low and insulin resistance is present ${ }^{8)}$. In terms of energy homeostasis, these observations are inferred to be compensatory mechanisms to inhibit food consumption in obese individuals. However, leptin was observed to decrease with weight-loss while ghrelin levels increased ${ }^{9-11)}$.

As mentioned previously, insulin resistance, which correlates with both leptin and ghrelin levels, refers to the state where physiological effects of insulin are decreased ${ }^{12)}$. Insulin interacts with leptin to decrease food consumption and inhibits secretion of ghrelin $\left.{ }^{13}, 14\right)$. In other words, leptin and ghrelin secretions are affected by insulin. It can be inferred that the increase in leptin and decrease in ghrelin observed in obese individuals are due to hyperinsulinemia, which is a result of insulin resistance ${ }^{15)}$.

Effective weight-loss exercises are known to decrease leptin and increase ghrelin levels ${ }^{16-18)}$. Furthermore, exercises are recognized as effective mediators to improve insulin resistance ${ }^{19-21)}$. Recent weight-loss interventions have focused on cardio and resistance trainings. Several studies reported that exercise effectively reduces indicators of obesity such as weight, body mass index (BMI), and body fat percentage ${ }^{22-24)}$. Circuit exercise, which alternates cardio and resistance exercises, is also known to effectively reduce body fat ${ }^{25}$. However, there is a lack of studies on the correlation between the diet-regulating hormones produced by circuit exercise and insulin resistance.

Therefore, it would be useful to investigate the changes in diet-regulating hormones leptin and ghrelin, as well as changes in insulin resistance, induced by circuit exercise in obese patients. This study investigated the effects of a 12-week circuit exercise program on indicators of obesity, diet-regulating hormones, and insulin resistance in middle-aged obese females.

\section{SUBJECTS AND METHODS}

The subjects of this study were 26 obese middle-aged women who were selected among participants in exercise class at K Region Health Promotion Center in South Korea and were randomly assigned to the exercise group ( $\mathrm{n}=13$ ) and the control group $(n=13)$. The participating condition of this study was excluded for women who had a body fat percentage of $30 \%$ or more, who had a dietary restriction within the last 6 months and regular exercise over 30 minutes. The exercise group performed circuit exercise for 12-weeks. The control group did not participate in regular exercise for 12-weeks in order to maintain the physical activity before the study participation period. All the subjects gave their written informed consent before participating in the study. This study was conducted in compliance with the ethical principles of the Declaration of Helsinki, and we obtained consent from the subjects after explaining in detail the objectives, methods, and expected effects of the exercise program. The physical characteristics of the subjects are shown in (Table 1).

Height and weight in the anthropometric test were measured in 0.1-cm increments using an automatic extensometer (Jenix DS-102, Korea). The body mass index (BMI) was calculated by the division of weight $(\mathrm{kg})$ over height $\left(\mathrm{m}^{2}\right)$. Body fat percentage was measured using a bioelectrical impedance analyzer (X-Scanplus II, Korea).

Blood test was performed using blood collected from an individual's forearm arteries after confirming the fasting state for 8 hours. Blood analysis items and measuring methods are as follows; reptin, ghrelin, insulin, fasting blood glucose were analyzed using a chemistry analyzer (Hitachi 7020, Japan). Insulin resistance test was calculated by means of the homeostastics model assessment of insulin resistance (HOMA-IR) method. The related formulais ${ }^{26}$. HOMA-IR $=$ [fasting plasma insulin $(\mathrm{uU} / \mathrm{ml}) \times$ fasting plasma glucose $(\mathrm{mg} / \mathrm{dl})] / 405$.

Circuit exercises were conducted 5 times per week for a span of 12 weeks. Warm-up consisted of 5 minutes of walking followed by 5 minutes of stretching. Ten minutes of stretching were added to each session as a cool-down. The main circuit exercise was composed of cardio (walking in place) and 5 types of weight-bearing resistance exercise (push-ups, squats, crunches, side lunges, and face-down leg/arm raises). Three sets were performed at each session for 30 minutes. The exercise intensity were set to $12-14$, based on the rating of perceived exertion. Sixty-second cardio motions and resistance exercises were performed in the following order: (1) walk in place, (2) push-ups, (3) walk in place, (4) squat, (5) walk in place, (6) crunches, (7) walk in place, (8) side lunges, (9) walk in place, and (10) face-down leg/arm raise.

To regulate food intake, participants were instructed to recall the previous 24 hours and to write down their food intake. The specified foods in the eating diary were analyzed using CAN-Pro 3.0 (Computer Aided Nutritional Analysis Program Version 3, Korea) to determine total energy consumption. Each participant was informed about her daily food intake restriction and was instructed to voluntarily cut down food consumption. 
Table 2. Change of obesity index

\begin{tabular}{lllll}
\hline \multicolumn{1}{c}{ Variability } & Group & \multicolumn{1}{c}{ Pre } & \multicolumn{1}{c}{ Post } & \multicolumn{1}{c}{$\Delta \%$} \\
\hline Weight $(\mathrm{kg})$ & Exercise & $82.7 \pm 10.4$ & $76.1 \pm 9.5^{* * *}$ & -7.9 \\
& Control & $77.2 \pm 9.6$ & $76.7 \pm 9.7$ & -0.6 \\
\hline Body mass index $\left(\mathrm{kg} / \mathrm{m}^{2}\right)$ & Exercise & $31.8 \pm 3.2$ & $29.4 \pm 3.0^{* * *}$ & -7.9 \\
& Control & $30.4 \pm 2.3$ & $30.2 \pm 2.4$ & -0.6 \\
\hline Body fat $(\%)$ & Exercise & $38.7 \pm 3.2$ & $36.9 \pm 3.5^{*}$ & -4.8 \\
& Control & $37.4 \pm 2.5$ & $37.6 \pm 2.1$ & 0.5 \\
\hline
\end{tabular}

Valves are Mean \pm SD. ${ }^{*} \mathrm{p}<0.05,{ }^{* *} \mathrm{p}<0.01,{ }^{* * *} \mathrm{p}<0.001, \Delta \%=[($ post - pre $) /$ pre $] \times 100$.

Table 3. Change of leptin and ghrelin

\begin{tabular}{ccccc}
\hline Variability & Group & Pre & Post & \multicolumn{1}{c}{$\Delta \%$} \\
\hline Leptin $(\mathrm{ng} / \mathrm{ml})$ & Exercise & $16.1 \pm 6.7$ & $13.9 \pm 5.5^{*}$ & -13.3 \\
& Control & $16.0 \pm 6.2$ & $20.0 \pm 5.7^{* * *}$ & 22.1 \\
\hline Ghrelin $(\mathrm{pg} / \mathrm{ml})$ & Exercise & $588.5 \pm 139.0$ & $821.4 \pm 197.0^{* * *}$ & 39.5 \\
& Control & $640.6 \pm 164.3$ & $560.9 \pm 125.3^{* * *}$ & -12.4 \\
\hline
\end{tabular}

Valves are Mean \pm SD. ${ }^{*} \mathrm{p}<0.05, * * \mathrm{p}<0.01,{ }^{* * *} \mathrm{p}<0.001, \Delta \%=[($ post - pre $) /$ pre $] \times 100$

Table 4. Change of insulin resistance

\begin{tabular}{llccr}
\hline \multicolumn{1}{c}{ Variability } & Group & Pre & \multicolumn{1}{c}{ Post } & $\Delta \%$ \\
\hline Fasting glucose $(\mathrm{mg} / \mathrm{dl})$ & Exercise & $87.9 \pm 7.0$ & $84.2 \pm 7.7$ & -4.1 \\
& Control & $89.3 \pm 9.1$ & $99.5 \pm 3.5^{* * *}$ & 11.4 \\
\hline Insulin $(\mathrm{uU} / \mathrm{ml})$ & Exercise & $7.6 \pm 1.7$ & $6.7 \pm 1.7^{*}$ & -11.4 \\
& Control & $7.5 \pm 1.4$ & $8.7 \pm 0.9^{* *}$ & 16.4 \\
\hline HOMA-IR & Exercise & $1.6 \pm 0.4$ & $1.4 \pm 0.4^{* *}$ & -15.0 \\
& Control & $1.6 \pm 0.4$ & $2.1 \pm 0.2^{* * *}$ & 27.9 \\
\hline
\end{tabular}

Valves are Mean $\pm \mathrm{SD} .{ }^{*} \mathrm{p}<0.05,{ }^{*} \mathrm{p}<0.01, * * * \mathrm{p}<0.001, \Delta \%=[($ post - pre $) /$ pre $] \times 100$.

The data in this study were analyzed using SAS (Statistical Analysis System, Version, 9.1). Two-way ANOVA by repeated measure was performed to test interaction effects on the measured variables between groups and measurement time. Statistical significance was set at $\mathrm{p}<0.05$.

\section{RESULTS}

As shown in Table 2, weight showed interaction effects between group and treatment $(\mathrm{p}<0.001)$. Interaction effect analysis results indicated that the exercise group showed a significant decrease from pre- to post-exercise $(\mathrm{p}<0.001)$, whereas the control group show a significant difference. Body mass index showed interaction effects between groups and treatment $(p<0.001)$. Interaction effect analysis results indicated that the exercise group showed a significant decrease from pre- to postexercise $(p<0.001)$, whereas the control group show a significant difference. \% body fat showed interaction effects between group and treatment $(\mathrm{p}<0.001)$. Interaction effect analysis results indicated that the exercise group showed a significant decrease from pre- to post-exercise $(\mathrm{p}<0.05)$, whereas the control group show a significant difference.

As shown in Table 3, leptin showed interaction effects between group and treatment $(p<0.001)$. Interaction effect analysis results indicated that the exercise group showed a significant decrease from pre- to post-exercise $(\mathrm{p}<0.05)$, whereas the control group showed a significant increase from pre- to post-exercise $(p<0.001)$. Ghrelin showed interaction effects between groups and treatment $(\mathrm{p}<0.001)$. Interaction effect analysis results indicated that the exercise group showed a significant increase from pre- to post-exercise $(\mathrm{p}<0.001)$, whereas the control group showed a significant decrease from pre- to postexercise $(\mathrm{p}<0.001)$.

As shown in Table 4, fasting blood glucose showed interaction effects between group and treatment $(p<0.001)$. Interaction effect analysis results indicated that the exercise group did not show a significant difference from pre- to post-exercise, whereas the control group showed a significant increased from pre- to post-exercise $(p<0.001)$. Insulin showed interaction effects between group and treatment $(p<0.001)$. Interaction effect analysis results indicated that the exercise group showed a significant decrease from pre- to post-exercise $(\mathrm{p}<0.05)$, whereas the control group showed a significant increase from pre- to post-exercise $(\mathrm{p}<0.001)$. HOMA-IR showed interaction effects between group and treatment $(\mathrm{p}<0.001)$. Interaction effect analysis results indicated that the exercise group showed a significant decrease from pre- to post-exercise $(p<0.05)$, whereas the control group showed a significant increase from pre- to post-exercise $(p<0.001)$. 


\section{DISCUSSION}

This study investigated the effects of a 12-week circuit exercise program, which alternates cardio and resistance exercises, on diet-regulating hormones and insulin resistance in middle-aged obese females. The results of this study showed a decrease in indicators of obesity — weight, BMI, and body fat percentage — after circuit exercises. Also, levels of the diet-regulating hormone leptin decreased, levels of the diet-regulating hormone ghrelin increased, and insulin levels decreased. The results showed effective improvements in insulin resistance.

In terms of weight regulation, the diet-regulating hormones leptin and ghrelin exert opposite effects in the hypothalamus and mediate each other ${ }^{27)}$. Leptin is secreted by adipose tissues and acts on the satiety center of the hypothalamus to restrict food intake. On the other hand, ghrelin is secreted by the gastric mucosa and acts on the hunger center of the hypothalamus, exerting the opposite effect of leptin ${ }^{28}$. Therefore, it was inferred that leptin levels would be decreased and ghrelin levels would be increased in obese individuals. However, it was found that leptin levels were increased in obese individuals due to leptin resistance, and ghrelin levels were down-regulated due to the compensatory mechanism of food intake restriction ${ }^{29,30)}$. In obese individuals, weight-loss causes decrease in leptin and increase in ghrelin levels ${ }^{9-11)}$.

Studies on exercises and diet-regulating hormones have reported a wide range of results, from no changes in leptin and ghrelin levels after acute or circuit exercises to increased levels of leptin with decreased level of ghrelin ${ }^{31,32}$. Also, previous studies have reported a decrease in leptin level and increase in ghrelin level following long-term exercises, which was attributed to the loss of body fat ${ }^{33,34)}$. In this study, indicators of obesity - weight, BMI, and body fat percentage - as well as levels of the diet-regulating hormone leptin were decreased after a 12-week circuit exercise program, while increased levels of ghrelin were observed. Therefore, it can be inferred that the decrease in leptin levels and increase in ghrelin levels were due to a negative feedback mechanism following weight loss in obese females. In other words, weight loss causes changes in diet-regulating hormone levels to regulate energy homeostasis.

When food is ingested, insulin is secreted by pancreatic $\beta$-cells. Insulin directly stimulates adipose tissues to promote leptin secretion and has similar functions as leptin in restricting food intake ${ }^{35)}$. Ghrelin is also regulated by insulin ${ }^{36)}$. Several studies have reported that leptin and ghrelin levels in obese individuals are influenced by insulin resistance ${ }^{37-39)}$.

Exercise promotes glucose uptake and is known to play an important role in increasing insulin sensitivity. Previous studies reported that both cardio and resistance exercises are effective in improving insulin resistance ${ }^{40,41)}$. Also, circuit exercises were observed to effectively improve the insulin resistance index (HOMA-IR) ${ }^{42,43)}$. In this study, although blood glucose levels were not significantly decreased after 12 weeks of circuit exercises, insulin levels and HOMA-IR were significantly improved. Therefore, it can be inferred that circuit exercises effectively improve insulin resistance, which is related to leptin and ghrelin, in obese females. These improvements in insulin resistance are expected to play an important role in obesityinduced cardiovascular problem prevention and type 2 diabetes prevention.

The limitations of this study were not to analyze the amount of physical activity in daily life affecting the weight change of exercise group and control group. Also, the daily intake of each individual was induced to induce voluntary dietary intake, but the dietary habits were not completely controlled. Despite these limitations, we have found that 12-week circuit exercise had positive effects on obesity index, leptin, ghrelin, and insulin resistance.

In conclusion, circuit exercises induced changes in the levels of diet-regulating hormones leptin and ghrelin through a negative feedback mechanism caused by a decrease in indicators of obesity in obese females. Also, it can be inferred that circuit exercises effectively improve insulin resistance.

\section{REFERENCES}

1) Brawer R, Brisbon N, Plumb J: Obesity and cancer. Prim Care, 2009, 36: 509-531. [Medline] [CrossRef]

2) Zheng W, McLerran DF, Rolland B, et al.: Association between body-mass index and risk of death in more than 1 million Asians. N Engl J Med, 2011, 364: 719-729. [Medline] [CrossRef]

3) Webber J: Energy balance in obesity. Proc Nutr Soc, 2003, 62: 539-543. [Medline] [CrossRef]

4) Elmquist JK: Hypothalamic pathways underlying the endocrine, autonomic, and behavioral effects of leptin. Int J Obes Relat Metab Disord, 2001, 25: S78S82. [Medline] [CrossRef]

5) Friedman JM, Halaas JL: Leptin and the regulation of body weight in mammals. Nature, 1998, 395: 763-770. [Medline] [CrossRef]

6) Minokoshi Y, Kim YB, Peroni OD, et al.: Leptin stimulates fatty-acid oxidation by activating AMP-activated protein kinase. Nature, 2002 , 415: 339-343. [Medline] [CrossRef]

7) Shintani M, Ogawa Y, Ebihara K, et al.: Ghrelin, an endogenous growth hormone secretagogue, is a novel orexigenic peptide that antagonizes leptin action through the activation of hypothalamic neuropeptide Y/Y1 receptor pathway. Diabetes, 2001, 50: 227-232. [Medline] [CrossRef]

8) Toshinai K, Mondal MS, Nakazato M, et al.: Upregulation of Ghrelin expression in the stomach upon fasting, insulin-induced hypoglycemia, and leptin administration. Biochem Biophys Res Commun, 2001, 281: 1220-1225. [Medline] [CrossRef]

9) Cummings DE, Weigle DS, Frayo RS, et al.: Plasma ghrelin levels after diet-induced weight loss or gastric bypass surgery. N Engl J Med, 2002, 346: 16231630. [Medline] [CrossRef]

10) Hansen TK, Dall R, Hosoda H, et al.: Weight loss increases circulating levels of ghrelin in human obesity. Clin Endocrinol (Oxf), 2002, 56: 203-206. [Medline] [CrossRef] 
11) Maffei M, Halaas J, Ravussin E, et al.: Leptin levels in human and rodent: measurement of plasma leptin and ob RNA in obese and weight-reduced subjects. Nat Med, 1995, 1: 1155-1161. [Medline] [CrossRef]

12) Grundy SM: Hypertriglyceridemia, insulin resistance, and the metabolic syndrome. Am J Cardiol, 1999, 83: 25F-29F. [Medline] [CrossRef]

13) Gale SM, Castracane VD, Mantzoros CS: Energy homeostasis, obesity and eating disorders: recent advances in endocrinology. J Nutr, 2004, 134: 295-298. [Medline]

14) Saad MF, Bernaba B, Hwu CM, et al.: Insulin regulates plasma ghrelin concentration. J Clin Endocrinol Metab, 2002, 87: 3997-4000. [Medline] [CrossRef]

15) Ikezaki A, Hosoda H, Ito K, et al.: Fasting plasma ghrelin levels are negatively correlated with insulin resistance and PAI-1, but not with leptin, in obese children and adolescents. Diabetes, 2002, 51: 3408-3411. [Medline] [CrossRef]

16) De Souza MJ, Leidy HJ, O'Donnell E, et al.: Fasting ghrelin levels in physically active women: relationship with menstrual disturbances and metabolic hormones. J Clin Endocrinol Metab, 2004, 89: 3536-3542. [Medline] [CrossRef]

17) Hickey MS, Houmard JA, Considine RV, et al.: Gender-depender effect exercise training on seurm leptein levels in humans. Am J Physiol, 1997 , 35: 562-566.

18) Littman AJ, Vitiello MV, Foster-Schubert K, et al.: Sleep, ghrelin, leptin and changes in body weight during a 1-year moderate-intensity physical activity intervention. Int J Obes, 2007, 31: 466-475. [Medline] [CrossRef]

19) Friedenreich CM, Neilson HK, Woolcott CG, et al.: Changes in insulin resistance indicators, IGFs, and adipokines in a year-long trial of aerobic exercise in postmenopausal women. Endocr Relat Cancer, 2011, 18: 357-369. [Medline] [CrossRef]

20) Janssen I, Fortier A, Hudson R, et al.: Effects of an energy-restrictive diet with or without exercise on abdominal fat, intermuscular fat, and metabolic risk factors in obese women. Diabetes Care, 2002, 25: 431-438. [Medline] [CrossRef]

21) Slentz CA, Houmard JA, Kraus WE: Exercise, abdominal obesity, skeletal muscle, and metabolic risk: evidence for a dose response. Obesity (Silver Spring), 2009, 17: S27-S33. [Medline] [CrossRef]

22) Ho SS, Dhaliwal SS, Hills AP, et al.: The effect of 12 weeks of aerobic, resistance or combination exercise training on cardiovascular risk factors in the overweight and obese in a randomized trial. BMC Public Health, 2012, 12: 704. [Medline] [CrossRef]

23) Jorge ML, de Oliveira VN, Resende NM, et al.: The effects of aerobic, resistance, and combined exercise on metabolic control, inflammatory markers, adipocytokines, and muscle insulin signaling in patients with type 2 diabetes mellitus. Metabolism, 2011, 60: 1244-1252. [Medline] [CrossRef]

24) Willis LH, Slentz CA, Bateman LA, et al.: Effects of aerobic and/or resistance training on body mass and fat mass in overweight or obese adults. J Appl Physiol 1985, 2012, 113: 1831-1837. [Medline] [CrossRef]

25) Davis JN, Gyllenhammer LE, Vanni AA, et al.: Startup circuit training program reduces metabolic risk in Latino adolescents. Med Sci Sports Exerc, 2011, 43: 2195-2203. [Medline] [CrossRef]

26) Matthews DR, Hosker JP, Rudenski AS, et al.: Homeostasis model assessment: insulin resistance and beta-cell function from fasting plasma glucose and insulin concentrations in man. Diabetologia, 1985, 28: 412-419. [Medline] [CrossRef]

27) Wilding JP: Neuropeptides and appetite control. Diabet Med, 2002, 19: 619-627. [Medline] [CrossRef]

28) Nakazato M, Murakami N, Date Y, et al.: A role for ghrelin in the central regulation of feeding. Nature, 2001, 409: 194-198. [Medline] [CrossRef]

29) Considine RV, Sinha MK, Heiman ML, et al.: Serum immunoreactive-leptin concentrations in normal-weight and obese humans. N Engl J Med, 1996, 334: 292-295. [Medline] [CrossRef]

30) Tschöp M, Weyer C, Tataranni PA, et al.: Circulating ghrelin levels are decreased in human obesity. Diabetes, 2001, 50: 707-709. [Medline] [CrossRef]

31) Broom DR, Batterham RL, King JA, et al.: Influence of resistance and aerobic exercise on hunger, circulating levels of acylated ghrelin, and peptide YY in healthy males. Am J Physiol Regul Integr Comp Physiol, 2009, 296: R29-R35. [Medline] [CrossRef]

32) Bouassida A, Chamari K, Zaouali M, et al.: Review on leptin and adiponectin responses and adaptations to acute and chronic exercise. Br J Sports Med, 2010, 44: 620-630. [Medline] [CrossRef]

33) Essig DA, Alderson NL, Ferguson MA, et al.: Delayed effects of exercise on the plasma leptin concentration. Metabolism, 2000, 49: 395-399. [Medline] [CrossRef]

34) Kraemer RR, Kraemer GR, Acevedo EO, et al.: Effects of aerobic exercise on serum leptin levels in obese women. Eur J Appl Physiol Occup Physiol, 1999, 80: 154-158. [Medline] [CrossRef]

35) Boden G, Chen X, Mozzoli M, et al.: Effect of fasting on serum leptin in normal human subjects. J Clin Endocrinol Metab, 1996, 81: 3419-3423. [Medline]

36) Broglio F, Arvat E, Benso A, et al.: Ghrelin, a natural GH secretagogue produced by the stomach, induces hyperglycemia and reduces insulin secretion in humans. J Clin Endocrinol Metab, 2001, 86: 5083-5086. [Medline] [CrossRef]

37) Fasshauer M, Paschke R: Regulation of adipocytokines and insulin resistance. Diabetologia, 2003, 46: 1594-1603. [Medline] [CrossRef]

38) Katsuki A, Urakawa H, Gabazza EC, et al.: Circulating levels of active ghrelin is associated with abdominal adiposity, hyperinsulinemia and insulin resistance in patients with type 2 diabetes mellitus. Eur J Endocrinol, 2004, 151: 573-577. [Medline] [CrossRef]

39) McLaughlin T, Abbasi F, Lamendola C, et al.: Plasma ghrelin concentrations are decreased in insulin-resistant obese adults relative to equally obese insulinsensitive controls. J Clin Endocrinol Metab, 2004, 89: 1630-1635. [Medline] [CrossRef]

40) Abd El-Kader SM: Aerobic versus resistance exercise training in modulation of insulin resistance, adipocytokines and inflammatory cytokine levels in obese type 2 diabetic patients. J Adv Res, 2011, 2: 179-183. [CrossRef]

41) Holten MK, Zacho M, Gaster M, et al.: Strength training increases insulin-mediated glucose uptake, GLUT4 content, and insulin signaling in skeletal muscle in patients with type 2 diabetes. Diabetes, 2004, 53: 294-305. [Medline] [CrossRef]

42) Miller MB, Pearcey GE, Cahill F, et al.: The effect of a short-term high-intensity circuit training program on work capacity, body composition, and blood profiles in sedentary obese men: a pilot study. BioMed Res Int, 2014, 2014: 191797. [Medline] [CrossRef]

43) Paoli A, Pacelli QF, Moro T, et al.: Effects of high-intensity circuit training, low-intensity circuit training and endurance training on blood pressure and lipoproteins in middle-aged overweight men. Lipids Health Dis, 2013, 12: 131. [Medline] [CrossRef] 